\title{
RITUAL FOLKLORE OF MONGOLIAN PEOPLES IN EDUCATION*
}

\author{
Aysa N. Bitkeeva ${ }^{1 * \star}$, Sesegma D. Gympilova ${ }^{2}$ \\ ${ }^{1}$ Dr.Sc., Leading Research Fellow, Research Center on Ethnic and Language Relations, Institute \\ of Linguistics of the Russian Academy of Sciences; Leading Research Fellow, A.M. Gorky Institute \\ of World Literature, Russian Academy of Sciences, \\ THE RUSSIAN FEDERATION, aisa_bitkeeva@yahoo.com \\ ${ }^{2} \mathrm{Ph} . \mathrm{D}$, Research Fellow, Institute for Mongolian, Buddhist and Tibetan Studies of Siberian Branch \\ of the Russian Academy of Sciences, \\ THE RUSSIAN FEDERATION, gymps70@yandex.ru \\ ${ }^{* *}$ Corresponding Author
}

\begin{abstract}
In the article the specific features of the ritual folklore of the Mongolian peoples and its role in ethnocultural educational objectives is considered on the example of folklore of the Mongolians, Kalmyks and Buryats.

There are objective factors that foster a rich diversity of folklore genres that Mongolian peoples have, including, most importantly, their traditional environment, their customs and traditions, their economic and everyday life structures, and their specific spiritual and material worlds based on the nomadic lifestyles, which they try to promote. Notably, the related peoples have a number of typologically similar features and specific characteristics that distinguish them from each other. Rituals are performed in accordance to their functions; they may be associated with the family, the calendar or the traditional type of economy, etc. A great variety of rituals and ceremonies accompanying the economic activities that the Mongolian peoples were engaged in (including hunting, fishing, cattle-breeding, and agriculture), as well as their richness in the family sphere (associated with births, weddings, funerals, etc.) contributed to the production of diverse poetical forms and formulas such as magic formulas, songs, well-wishes, curses, magtal (praises), etc.
\end{abstract}

Thus, ritualistic folklore is a unique part of the Mongolian peoples' traditional heritage that should be approached by scholars, with its evolutionary development taken into account and the ritualistic system reconstructed. Also of importance is an awareness of the contemporary folklore practice. The traditions and rituals of the Mongolian peoples are illustrative of their lifestyles, economic activities, everyday life and nomadic cultures. While involved in traditional cattle breeding and travelling from place to place the nomads adapted to their mostly harsh environments that they used to worship and respect and, most importantly, created their oral ritual poetry, quite unique in terms of themes and artistic imagery. It has a variety of distinct features: it is of an ancient origin and has been observed from ancient times; some of it can be dated back to early hunters preserved in its original form without any corruption in terms of semantics and stylistics; it is in fact a synthesis of appropriate actions and ceremonies that combine alongside ritual practices songs, dances, melodies, worship ceremonies, well-wishes, and praises. The ceremonies can be categorized in terms of their genres, types, and varieties; they are mostly kept alive, some of them still of relevance in the present day realities. The nomadic ritualistic practices are a part of the common heritage and history of the cattle breeders. Their culture is rich in traditions illustrative of their lifestyle, trades and arts, mentalities,

\footnotetext{
"The reported in the article study was funded by RFBR and DFG, project number № 21-512-12002 HHИO_a "Prognostic methods and future scenarios in language policy - multilingual Russia as an example".
} 
thinking and ideas, beliefs and religions. They have unique perspectives, perceptions, concepts, and worldviews that gave rise to their traditional culture and nomadic civilization. All these ethnic knowledge and skills should be documented, researched and transferred to the young generations.

Keywords: ritual folklore of Mongolians, Kalmyks, Buryats

\section{INTRUDUCTION}

The most archaic genre of oral traditions is ritualistic folklore, which reflects the people's belief in the magic power of the word. Hence the belief in the power of the word contributed to the production of diverse folklore forms. Every people or ethnic group has their own unique rituals and ritualistic poetry associated with them. There are objective factors that foster a rich diversity of genres that Mongolian peoples have, including, most importantly, their traditional environment, their customs and traditions, their economic and everyday life structures, and their specific spiritual and material worlds based on the nomadic lifestyles, which they try to promote. Notably, the related peoples have a number of typologically similar features, but also specific characteristics that distinguish them from each other. The popular poetry of Mongolian peoples vividly demonstrates their culture and everyday life, as well as reveals the character of the worldview their ancestors had while creating their folklore productions that served to accompany their ritual activities.

It is true that many of the rituals produced within the contexts of particular historical periods and their social structures are gradually disappearing with the advance of modernity. However, the poetry that was produced in the context of traditional nomadic lifestyle of the peoples continues even in the modern societies because of their firm connections with the mentality and tradition inherited from the ancestors.

The main motif of this poetry is well-wishing aimed at contributing to the realization of desires such as prosperity in the household affairs and economies, with the cattle preserved and growing, with the good weather, and, most importantly, achieving happiness and well-being, staying in good health, and fostering goodness to overcome evil. A great role in realization of such wishes is ascribed to the will of the protector, i.e. a god, a totem of a clan or an outstanding personality who is known for his/ her significant achievements for the goodness and prosperity of the people.

In the article we consider the specific features of the ritual folklore of the Mongolian peoples and its role in ethnocultural educational objectives on the example of folklore of the Mongolians, Kalmyks and Buryats.

The reported in the article study was funded by RFBR and DFG, project number № 21-512-12002 HНИO_a "Prognostic methods and future scenarios in language policy - multilingual Russia as an example".

\section{RESULTS}

Rituals are performed in accordance to their functions; they may be associated with the family, the calendar or the traditional type of economy, etc. A great variety of rituals and ceremonies accompanying the economic activities that the Mongolian peoples were engaged in (including hunting, fishing, cattle-breeding, and agriculture), as well as their richness in the family sphere (associated with births, weddings, funerals, etc.) contributed to the production of diverse poetical forms and formulas such as magic formulas, songs, wellwishes, curses, magtal (praises), etc.

\subsection{Calendar Ritualistic Poetry of Mongolian Peoples}

The calendar ritualistic poetry of Mongolian peoples is multifarious in terms of genres, content, motifs, and artistic expressive devices used; it is grouped into four cycles in accordance with the seasons of the year and solstices (spring, summer, autumn, and winter).

According to the lunar calendar of the twelve-year cycles, the beginning of the year corresponds to the vernal equinox marked with the Mongolian "Tsagaan Sar", Kalmyk "Tsagan Sar", and Buryat "Sagaalgan" festivals, celebrated annually from the second half of February or the beginning of March each year. With the beginning of the spring festival children and young people used to make visits to their relatives and friends and by way of well-wishing sing praises to the hosts and perform songs; pastries made in the form of pancakes and figurines and fried in oil (Kalm bortsyki, Bur and Mong boovy) were both presented and accepted. 
However, the Kalmyks followed this ritual up to the mid-fifteenth century; it was changed with the introduction of a new account system starting in the middle or late autumn, when they began to celebrate the New Year's ritual feast "Zul". With the development of their religious ideas the people would believe and hope that by performing the necessary rituals and ceremonies and summoning divine powers, they would get the support and aid of these powers to promote their well-being and prosperity. Saying farewell to the Old Year and welcoming the New Year, the Kalmyks perform appropriate religious ceremonies and express their wishes of a peaceful sky, a Happy New Year, good health, abundance of food and drink, fertility of land and cattle for the good of their friends and family. The purpose of such ritual celebrations is especially apparent in wellwishing formulas accompanying their performance.

Summers were celebrated by the Mongols with their "Nadom" festival, the Kalmyks had their "Ur Sar" celebrations, and the Buryats marked the season with their "Surharban" (literal: archery). The festivities are usually arranged on the eve of hay harvesting, after spring field work is over. They are marked by all kinds of contests and rivalries aimed at testing the accuracy and strength of the competitors. Archery contest is followed by wrestling, with the winner praised in a special poem devoted to the event and the victor. Racing is held as the final event of the festivities, the horse that wins the race is also praised in a song.

The ancient magic of hunters and cattle-breeders formed the basis for the development of rituals associated with sowing and harvesting. The autumn ritualistic songs and games were now celebrated after the harvest season and preparations began in early autumn. Before the sowing of winter rye the Buryats went out into the field, made a fire on the boundary and cooked salamat (Buryat traditional dairy meal). While adding butter to the fire, the head of the family appealed to burhan.

\subsection{Family Ritualistic Poetry of the Mongolian Peoples}

The family ritualistic poetry of the Mongolian peoples is a complex and multifarious phenomenon, which includes pieces of different periods and of diverse genres varying from simple formulas to elaborate forms of popular poetry. There is, however, an important feature characteristic of every one of them - they all have a close connection with the magic acts with which they constitute unified ritualistic complexes. The ritual ceremonies were performed when appropriate and necessary at important moments of the family life.

Birth rituals have a significant degree of stability; they have been reproduced for many centuries supported both by the customs and traditions and prejudices of the peoples. They open the life cycle of an individual and that is why there is a special emphasis on the event of the birth of a child who is seen as the heir and successor of the family. The period between the child's birth to the age of its majority was accompanied by a variety of rituals and ceremonies of a protective character, which were based on ancient religious ideas of the Mongolians.

During pregnancy it was crucial for a woman to observe certain regulations and restrictions that aimed at ensuring the well-being of the future mother and her child. Most of the restrictions are based on the principles of contagious, imitative, and partial magic; this shows a constant appellation to protective magic practices that is still of relevance today. The Mongolian peoples had numerous restrictions that pregnant women were to observe. They were not to do any heavy work and were carefully looked after so that they did not have any worries. They were recommended to avoid weddings and funerals, as well as follow certain food regulations.

The birth of a child in the Kalmyk, Buryat, and Mongolian family was a happy event to be marked by various rituals and practices of a sacral character. The Kalmyks observed the following ceremony: when a son was born to a Kalmyk, one of the assisting women was to announce the father's name. The father and all the men present at the time were stripped of their hats to be returned to them in exchange for some sums, which were then given to the women who helped the child-giving woman. Also, on the day a son was born they cooked a lamb's leg to carefully strip the tibia from meat and hide in a box. The bone belonged to the newborn. If a woman gave birth to twins her status in the family was automatically raised. The Kalmyk solution to the argument about who of the twins was the elder was quite original; they thought it was the one who was last and who gave way to the younger one.

The birth of a child was a big event for the family but also for the whole clan. Parents invited relatives to a festive meal who arrived with presents. Most of the presents were of a protective character and were aimed at ensuring the magic protection of the clan in future. The family were concerned about the child's health and well-being and ensured it by observing magic practices. For example, with Buddhism spreading among the Kalmyks, it became customary that a newborn was provided with a personal amulet $(b u)$ based on pertaining astrological data. This was usually a piece of paper with prayers written down on it that was enwrapped with cloth or leather. 
The original complex of Buryat birth practices and ceremonies included a ritual known as "toontolho" (or "toontomaltaha"), i.e. the placenta burial ceremony. The Buryats believed that the practice was crucial for the child's life. The placenta was associated with the child's soul and the child's further life depended on measures taken about it. The Shamanist Buryats thought that for the newborn to be well his (her) placenta had to be safely secured and protected from any evil spirits. The ceremony was performed by carefully selected elderly women, their number limited to a group of three, five or seven people (these numbers have a sacred meaning with the Mongolians). In the north-west part of the yurt behind the fireplace the floor board was removed and the woman who had given birth to a child put a silver coin there. The women taking part in the ceremony made a hole in that very place, covered its bottom with a piece of felt, put some wool on it, then some grains and the right hind leg of a lamb and finally the placenta on top of this; and the hole was filled with earth. After this it was time to cook salamat. A fire was made over the placenta burial place and the young mother and participants of the ritual took place round it. The bowl with salamat was passed from woman to woman in a circle and each of them was to take some of it and throw onto the burial (into the fire) first and then ate some of it herself. This was the final act after which the board was put in place again. The end of the ceremony was celebrated by a feast with well-wishing speeches made in honour of the newborn that was believed to be safe from any harm and to grow and bring only happiness to his (her) parents now that the placenta was buried.

Notably, traditional practices of using various objects were observed in the ceremony. Each of the objects had a meaning and each of the acts performed was accompanied with verbal magic formulas. The objects that were used in the placenta burial had special functions because each of them was designed to pass over the desired qualities characteristic of them to the child. For example, a piece of coal was put to symbolize fire or grains were put so that the child in question was healthy and in future had his own numerous offspring like grains (imitative magic). A silver coin used in the ceremony was put in the hole so that a long life of the newborn was ensured. This was accompanied with the following words (Buryat) "Mungendli munhe nahatai bolo", i.e. "Have a long life like this silver". Birch twigs were also used in the ceremony as one of the sacred objects to ensure that a child had a long and healthy life (imitative magic). The magic formula in this case was "Huhan modondli namshahalzha, namaalzha bai". i.e. "Like a birch, covered with leaves, breed and propagate". The main function of the objects was the protection from evil influences that they secured for the placenta. This was enhanced by the effect of the incantations repeated with the acts performed to achieve the desired ends. The formulas cited above are illustrative of their general character: they are as a rule laconic and brief and express the main idea; characteristic of them are the forms of the imperative mood, which is justified by their function of ensuring the desired results.

The placenta burial was an important ritual for the Buryats who ascribed a crucial role to it. The acts associated with the practice were based on the ancient religious beliefs of the people. With the changes in the family sphere, many of the elements of the ritual lost their relevance; some of them were either forgotten or acquired new meanings.

Importantly, the newborn was showed with presents. Women brought clothes such as skins of domestic animals or shirts or gave money. Some of the relatives presented the child with sheep, calves, lambs, etc. A boy would receive presents pertaining to his male status such as a knife in a sheath, arrows and a bow, a saddle. In return, depending on their resources, the young parents were also supposed to give presents to their guests; the old men had shirts, the women were presented with silk kerchiefs or were given gold or silver coins. The festive meal followed with well-wishes addressed to the newborn and its parents. Words of praise were various in terms of their structure and content. Let us give examples of well wishes to the child:

\begin{tabular}{|l|l|}
\hline In Вurуat: & \\
Наһанайнгаа харгыда & Let your life path \\
Дуурэн һанаатай, золтой & Be full of golden dreams, \\
Яргалтай ябаарайш. & Good luck and happiness to you. \\
Үйндоо хурэжэ & A year will pass - \\
Үетэноороо наадажа & With peers you will be sporting, \\
Арба хурэжэ - аляархажа ябаарайш. & In ten years you will be playful \\
Үдэр ерэхэ бури & Day after day \\
Үндэр боложо, & Taller you will become, \\
Жэл ерэхэ бури & Year after year \\
Ехэнууд боложо байгаарайт. & Grow and become mature! \\
\hline
\end{tabular}


These well-wishes are very similar to incantations in their composition, structure, and content, which may be an indication of their genetic association. Originally they were verbal formulas of a magic character aimed at ensuring the happiness and well-being of their addressees. With their magic function gradually lost, they were perceived as works of verbal art to be aesthetically enjoyed. The elaboration of their imagery, symbolism, and poetics (such as hyperbole, comparison, epithet, etc.) led to the perfection of their artistic character. At present well-wishes is one of the most spread and actively employed types of the oral poetry of the Mongolian people's so that every festive event is an occasion for using them.

When a child was twelve months old, it was time for a complete shave of its head because Mongolians believed that if the hair with which it was born was not removed the child would suffer from headaches for the rest of its life. Notably too, the hair was not then burned or thrown away; it was to be put and safely sewn into the child's mattress or pillow. The observance of the ceremony guaranteed that the children would grow strong, healthy and happy. The event marked the end of the infancy period as well. The ritual of the first cut of the child's hair was not only associated with the next stage in its growth but it also signalled a distance from 'the world of ancestors and gods' and a greater affinity of the child with its social environment. Today, however, this practice has lost its importance and if observed the ceremony is much more simplified; but even in their reduced form the acts performed serve as a protective measure against evil spirits.

\subsection{Wedding Poetry of the Mongolian Peoples}

Notably, of all the numerous Kalmyk, Buryat, and Mongolian customs and ceremonies the attention was mostly paid to the wedding and the rich poetry associated with it; hence they were described in great detail. The wedding traditions with their ritualistic poetry stand out among other such practices by a significant role they play in these cultures.

According to Mongols, marriage was an event of the state importance and it was performed as a nationally relevant ritual. When visiting the bride's yurt on the occasion of asking her to marry a young man, the guests would address her father with the following speech: "Our matter is of state importance. We have arrived with the good news concerning our children". Also, there is a proverb that shows the utmost importance ascribed to the event by the people who say "We have been busy with building a fence round the khan's land; we have been busy with arranging another family for this nutug".

There is a whole variety of ritual events that constitute the ceremony of Mongolian, Kalmyk, and Buryat weddings to be performed in an orderly manner; both the sides of a bridegroom and bride are actively engaged in the activities that often turn into a contest for the best song, well-wishing speech, etc.

Conversely, funerals and funereal rituals, as well as popular poetry associated with them showed the sadness and grief of the people for the dear members of a family and clan that passed away. In the perception of Mongolian people's death was an evil power but also an exercise of the divine will that took away people into a special world. In ancient times they believed that in that realm of the dead they continued to lead ordinary lives similar to those they had before they died. But also their lives there could be happy or full of sorrows and suffering; which of these was to be the destiny of the deceased depended on the material aspect of the funeral and after-funeral ceremonies observed or neglected by their relatives. Verbal formulas in the spirit of the sad occasion are part of these rituals as well.

\subsection{Poetry of Labour and Work of the Mongolian Peoples}

Cattle breeding, the main economic activity of the Mongolian peoples has been practiced by them since the time immemorial. Much depended in this area on seasons and periods of solstice, as well as on favourable and unfavourable environments that the people took into account. Accordingly they would move with their cattle and households from winter pastures to spring ones, from spring pastures to summer ones and then from those to winter quarters again. The ancient ritual practices associated with the popular calendar events had a solar orientation. The sun on which life itself depended had a cultic status with the Mongolians.

They would breed five types of cattle, including horses, sheep, cows and bulls, camels, and goats. The Mongols, Kalmyks, and Buryats have developed their cultures of cattle breeders marked by an expertise in looking after their cattle and the pastures they had for them, in taking all kinds of preventive measures against evil-doers, as well as in using popular veterinary practices against animal diseases.

They believed that the cattle they had been given to them by their gods and directed all their economic activities to preserving and enumerating as much as possible their riches. Nevertheless, they did sometimes have losses, which happened for a number of reasons including animal illnesses, excessively cold weather or lack of fodder. Also, this happened when a she-camel, a cow, or an ewe would refuse to accept their 
young. For such cases the cattle breeders used a number of popular methods, their success depending to a degree on incantations and magical formulas accompanying the respective acts. These were first of all taming practices that included, depending on the particular case, special techniques that helped to establish proper relations between the animal and its young. Songs, dombra melodies, incantations were quite helpful as well.

To illustrate, Kalmyks were especially attentive to the young of the camel, generally known for weakness, timidity, and fearfulness, and had special techniques of approaching them. The camel which gave birth to its baby is sensitive to smells and may refuse to accept it if it feels any unpleasant trace left by a stranger's touch or if it was enwrapped in the smelly or dirty piece of cloth. In the case of the mother's indifference to its own young a special ceremony was to be performed, with the young people collected to sing songs and play the dombra. Konstantin Erendzhenov, the famous Kalmyk poet, for example, left the following description: "The girl plays the dombra and leads the camel round its young lying on the ground (a rope is attached between her right hand and the animal), with everyone present on the scene singing a song" (Erendzhenov, 1990: 29). Similar practices are known among Mongols and Buryats as well.

Let us give an example of the folklore used in such ceremonies:

\begin{tabular}{|c|c|}
\hline In Kalm.: & The stream is gurgling \\
\hline Булгин усн кезә & And will not dry up, \\
\hline Ширгнә болһнач? & Bobn-bobn bojula! \\
\hline Бобн-бобн божула! & The meadow and the willow crowd \\
\hline Бурһсн модн кезә & They will ever remain green. \\
\hline Буйсна гинәч? & Bobn-bobn bojula! \\
\hline Бобн-бобн божула! & There is no end to the ocean, \\
\hline Шарк нертә дала & So deep and revered, \\
\hline Кезә ширгнә болһнач? & And baby of yours, \\
\hline Шилв уга үриһән & So tiny and long legged, \\
\hline Кезә босна болһнач? & Will take time to grow! \\
\hline Бобн-бобн божула! & Bobn-bobn bojula! \\
\hline Хом арһмжар хомлулад уга & It does not know \\
\hline Бобн-бобн божула! & A rope tight, \\
\hline Хойр бөкәрн сердүләд уга & Bobn-bobn bojula! \\
\hline Бобн-бобн божула! & Its humps are still free of cargo, \\
\hline Уньн, термәр & Bobn-bobn bojula! \\
\hline Хомлулад уга & It has not carried the yurts, \\
\hline Бобн-бобн божула! & as well as other burden, \\
\hline Удцн маралж & Bobn-bobn bojula! \\
\hline Киисгәд уга & Its nose is still intact \\
\hline Бобн-бобн божула! & It has not been penetrated by \\
\hline Темн зүүһәр & a thick needle, \\
\hline Хатхулад уга & Its legs are still so weak, \\
\hline Бобн-бобн божула! & Bobn-bobn bojula! \\
\hline Тең, бөрвән тинилһәд уга & The stream is gurgling \\
\hline Бобн-бобн божула! & And will not dry up, \\
\hline
\end{tabular}




\begin{tabular}{|l|l|}
\hline Булгин усн кезә & Bobn-bobn bojula! \\
Ширгнә болһнач? & But when the baby born \\
Бобн-бобн божула! & Will gets its legs? \\
Бурhсн модн кезә & Take it and caress what is yours. \\
Буйсна гинәч? & Bobn-bobn bojula! \\
Бобн-бобн божула! & \\
\hline
\end{tabular}

Seasonal travels to summer and winter camps were accompanied by rituals familiar to the nomad since their childhood. Such trips were the only solution to be sought in case calamities, as well as undertaken for the sake of their careful and economical use. Good pastures had to be looked for far and near and the nomadic cattle breeders travelled with their cattle and households from place to place in summer and in other seasons as well. Between November and March they usually stayed in their winter camps but with the beginning of spring they left them for summer quarters. The elders took such opportunities to make their well-wishing speeches.

In spring the Mongolian peoples used to practice cutting the mane and tails of their horses. It was usually the men who caught both tame and wild horses to do the trimming. Songs performed afterwards were full of wishes for horses to be healthy and strong, wolves to be escaped and good pastures with rich grasses to be found for the horses to flourish and serve their masters.

Hunting is one of the earliest activities known to man. Since time immemorial many rituals and practices associated with it have been observed; these were accompanied with well-wishing speeches, magic incantations, songs, and dances. For example, before they went on a hunting expedition Buryats used to have a special ritual that included cleansing of their hunting clothes by way of throwing some portion of milk vodka on the clothes, addressing the eternal heavens, the host spirits of mountains, taiga and presenting them with food to please them and hence succeed in their undertaking.

Farming is also one of the oldest economic activities associated with a richness of ritualistic practices. But it is of less importance for the cattle breeders except for some particular groups that lived next to agricultural societies known for their long standing tradition in farming. Such groups developed certain customs and ceremonies, songs and other verbal art forms characteristic of agricultural cultures such as those associated with choosing plots for farming, the sprinkling of land for sowing, preparing it for ploughing and sowing, the irrigation activities, as well as the rituals associated with harvesting, threshing, etc. Notably, these were based on their ancient hunting and cattle breeding magic practices.

Thus, for example, Buryats borrowed from Russians some of their farming customs and ceremonies. Like other farmers they prepared for agricultural work in the autumn, going out, for example, to the fields before sowing their winter rye to make fire on the boundary and cook some porridge. Sprinkling the fire with butter, the eldest member of the family appealed to burhan with the following words:

\begin{tabular}{|l|l|}
\hline In Вuryat: & Burhan, our father, \\
Бурхан баабаймнай, & Be kind and benevolent \\
Гэр булэдэм ан гуроол заяагты! & And grant your favor to my family \\
Зоохэй тоһондо хуртэгты! & Help yourself to our salamat and butter! \\
Зол жаргал уршоогты! & Happiness and well-being we ask you to grant \\
Ерэхэ жэлдэ & A good harvest from you we ask in the coming \\
hайн ургаса уршоогты! & year. \\
& \\
\hline
\end{tabular}

\subsection{Religious Rites and Poetry of the Mongolian Peoples}

This is quite a unique category in the Mongolian folklore. The ritual practices of Mongols, Kalmyks, and Buryats in this area derive from ancient customs, incantations, well-wishes, and beliefs that they had even before they developed their pagan religious worldviews. These are, for example, the rituals and ceremonies of worshiping and giving presents to the sun, the moon, and the stars, with incantations and magical 
formulas used in addressing them.

In particular, the Kalmyks, Mongols, and Buryats pay homage to the ancestral spirits, addressing them with magic formulas. The Mongols describe this as "hald deej örgöh", for the Kalmyks this is the "hal tyääh" ceremony, and the Buryats call it "galda yurgehe" (i.e. the ceremony of fire worship). Well-known is the enormous role of fire in the evolution of man and human society; and this tradition goes back to the early period in the human history. According to an ancient Mongolian saga it was the heavens that granted fire to man by putting it into a flint stone. The wise old man Sahyaday Ubegen was the first to get the fire using the flint stone and man started its fire worship since that very moment. Fire was believed to be the source of purity and its symbol; it had a magic quality of bringing wealth, luck, and happiness too. To prevent droughts and fires, to avoid illnesses, and to succeed in their cattle breeding activities, the people thought that it was necessary for them to "please" fire every day with the first drops of milk from their cows or with tea and food. Once a year they held a bigger solemn ceremony with worshipping, praying and bringing their presents to the god of fire. It was a great ceremony that consisted of several stages such as preparations, the worship acts, and concluding ceremonies and practices.

Kalmyks, Buryats, and Mongols have other rituals as well, including those associated with the worship of the Wise Old Man, who is believed to be the protector of life and grantor of long years, as well as the symbolic figure in the Buddhist pantheon whose sphere is fertility and well-being; or those of worshipping mountains and $o b o$ and the host spirits of particular localities and places.

Also, Mongols and Buryats have traditions and customs associated with their traditional pagan beliefs and Shamanism such as the ceremonies they hold to worship the ninety nine tengri, as well as reciting poetry devoted to protecting spirits, Shamanistic formulas, etc. One of such traditional ceremonies still of relevance today is, for example, the ceremony of appealing to the soul of a man, which is practised in particular by Buryats in the Kurumchi valley (Bayandayevsky raion of the Irkutsky Oblast'). The ancient man believed that the soul could leave man's body if he (she) was scared out of his (her) wits. To guide the soul back and restore the well-being of the sufferer, it was appealed in the following way:

Uyg hury!

Do not stand hunched over behind

Your father's gold-silver horse hitching post,

Come back!

Look at grandmother who assisted in your birth

Uyg hury!

If scared - turn into air!

Feeling timid - show your face!

Be happy and live your ninety years!

A hundred years!

Come back!

Uyg hury!

(S.S. Bardakhanova recorded this poetry from U.P. Hamaganov in 1975; he was born in 1928 in the village of Gushit of Ehirit-Bulagatsky raion of Irkustskaya Oblast').

Lamaistic practices and oral poetry such as praises, poems, shastry, and religious songs. Religious faith and ideas are manifest in the traditional practices of Mongols, in their ceremonies of worship, praying, wellwishing, and presents that they devoted to invisible spirits, protectors, deities, the powers of the heavens, fire, mountains, and steppes. According to researchers, the ritualistic poetry accompanying such practices is represented in numerous particular forms, including prayers, addresses, supplications, appeals to gods and deities, incantations, vows, maani, etc. (Gantogtoh, 2007: 233).

\section{CONCLUSION}

The genres of the Mongolian ritual folklore have a number of functions. Well-wishing speeches and addresses are one genre that seems to be appropriate for every occasion. They are used to express the 
best possible feelings and wishes to their addressees such as happiness, good health, success and achievement in their working places, piece and well-being. The particular content of such formulas on the indicated themes may be various. Their close association with ritualistic practices was pointed out by B.Y. Vladimirtsov. He argued that "yoral" are well-wishes but also vows. Some of them incorporate the traces of religious-lamaist mythology that indicates that they go back to ancient epochs. Many of them sound as incantations and wishes form only a part of their content. In old times the formulas used in the context of ritualistic practices were to contribute to the success of any undertaking, as well as to the health and wellbeing of the individuals involved. For example, following their traditions and commenting on the well-wishes addressed to them, Kalmyks, would say "Yoryal shingthya!" (Let the words reach their end!) or "Tiigthya!" (Let it be!)

Most ancient of the oral ritualistic poetry are incantations and magic formulas, which originated with the development of mythological worldviews of the peoples. They were wide spread among masses who believed in the magic power of the word and in particular situations would resort to them seeking to find solutions to their problems. This genre of folklore can be subcategorized into i) a group of formulas indicative of trades and arts of the peoples (such as hunting, cattle breeding in this case); ii) a group of incantations designed to treat illnesses or bodily dysfunctions or prevent them; and iii) a group of formulas used in everyday life.

For example, before going on hunting expeditions, Buryats, following their Shamanistic tradition, would first perform the ceremony of cleansing the hunting equipment and clothes by sprinkling them with dairy products and wine and addressing to the power of mountain and taiga spirits to attract them to their side and ensure their success. The people were quite particular in their addresses. For, example, they would say in Buryat: "Bugyn targanhan, bulgani harahan ugooreyt!" (Grant to us the fattest of the mooses and the darkest of the sables!) Also, the ceremony master would have a bundle of silk threads of different colours and light one of its ends to brush the hunters' lips and chins to remove any wounds and bruises with an incantation in Buryat: "Ulaan utahaar oroynom, huhe utahaar hureelnem" (Brushing with a red thread, brushing with a blue thread). Similar treatments were applicable in the case of a swollen finger, "horhoyn nyuden" (lit.: a worm's eye). Those involved in the procedure believed in its effectiveness; and the informants would report the complete success of such remedies.

The magic formulas and incantations may be related to well-wishing words and speeches but they differ from the latter in terms of their addressees and, also, in structure. In fact they indicate a different kind of relation towards particular instances of their real environments. At present, however, it is rare that an incantation is used at all; they are disappearing from everyday life.

One of the most important components of the ritualistic system is musical accompaniment. The Mongolians' initiation rituals included, beside magic practice, well-wishes and incantations, ritual singing and the songs performed were semantically related to the theme of a change in the status of a person, the addressee of this practice. Unfortunately, so far little has been done in the field of Mongolian ethnic musicology in terms of the music and songs used to accompany birth, wedding, and funeral rituals.

In general, however, it may be noted that ritualistic songs are an ancient type of such folklore of the Mongols, Kalmyks, and Buryats. They are first of all related to family life, hunting and cattle-breeding, and farming. Songs accompanied ritual practices observed on certain dates of the calendar in spring, summer, autumn, and winter. In accordance with the ancient beliefs of the peoples, when performed in their presence the rituals and songs were a way of promoting their successful hunting, growth of their herds, and good health and well being of the people. The ritualistic songs with their magic content were an integral part of the rituals; songs of incantations addressed divine powers and protectors to win over their favours such as good health, happiness, etc.; and songs of praises had as their addressee a particular person to whom the festivities and rituals were devoted.

Thus, ritualistic folklore is a unique part of the Mongolian peoples' traditional heritage that should be approached by scholars, with its evolutionary development taken into account and the ritualistic system reconstructed. Also of importance is an awareness of the contemporary folklore practice. The traditions and rituals of the Mongolian peoples are illustrative of their lifestyles, economic activities, everyday life and nomadic cultures. While involved in traditional cattle breeding and travelling from place to place the nomads adapted to their mostly harsh environments that they used to worship and respect and, most importantly, created their oral ritual poetry, quite unique in terms of themes and artistic imagery. It has a variety of distinct features: it is of an ancient origin and has been observed from ancient times; some of it can be dated back to early hunters preserved in its original form without any corruption in terms of semantics and stylistics; it is in fact a synthesis of appropriate actions and ceremonies that combine alongside ritual practices songs, 
dances, melodies, worship ceremonies, well-wishes, and praises. The ceremonies can be categorized in terms of their genres, types, and varieties; they are mostly kept alive, some of them still of relevance in the present day realities. The nomadic ritualistic practices are a part of the common heritage and history of the cattle breeders. Their culture is rich in traditions illustrative of their lifestyle, trades and arts, mentalities, thinking and ideas, beliefs and religions. They have unique perspectives, perceptions, concepts, and worldviews that gave rise to their traditional culture and nomadic civilization.

\section{REFERENCE LIST}

Bardakhanova, S.S. (2007) Sovremennoye bytovaniye buryatskogo fol'klora. Ulan-Ude.

Gantogtoh, G. (2007) Mongol zan yuiliyn aman yaruu nayrgiyn ulamzhlal. Ulan-Bator.

Erendzhenov, K.E. (1990) Zolotoy rodnik. Elista. 